\title{
THE CORRELATION OF USABILITY, FAMILIARITY, SATISFACTION AND REPUTATION WITH THE LOYALTY OF STUDENT USERS OF NEWS WEBSITES
}

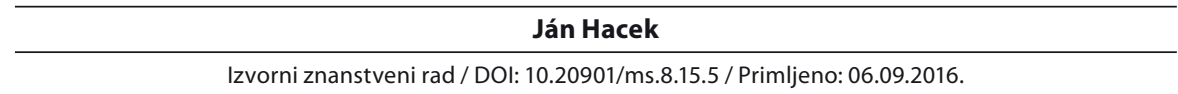

Izvorni znanstveni rad / DOI: 10.20901/ms.8.15.5 / Primljeno: 06.09.2016.

\begin{abstract}
In a time of increasing competition in online news, it is important for the publishers of news websites to retain loyal users. This paper contributes to the study of loyalty through an investigation of the factors that affect the loyalty of young users of news websites and motivate them to return there. The research sample in this study was made up of students $(N=408)$ at universities in Slovakia who use news websites to search for information every day. Correlation and regression analyses have been used to test the hypotheses. The results of this research confirm that usability, familiarity, satisfaction and reputation have a direct and positive relationship to the users' loyalty as reflected in daily use of a news website. The correlation shows that loyalty is associated particularly closely with reputation and satisfaction with a selected news website. Regression analysis shows that there are also other variables that affect users' loyalty.
\end{abstract}

KEY WORDS

LOYALTY, CORRELATION, NEWS WEBSITE, STUDENT USER, LOYAL USER

Author note

Ján Hacek :: Comenius University, Faculty of Arts, Department of Journalism, Bratislava, Slovakia :: jan.hacek@uniba.sk 


\section{INTRODUCTION: DIGITAL NEWS CONSUMPTION}

A survey of the media market in the Europe shows that many websites are naturally dedicating their efforts to stabilising their position (Reuters Institute, 2016). This is especially true for news websites which are in some measure an extension or alternative to the print editions of daily newspapers. There is still much that is unknown about the new digital media and they are frequently less than clearly defined in the theory of modern journalism. The area in question is nevertheless one in which academic and commercial researches are keen to map the behaviour and consumption patterns of the online public. The digital editions of newspapers are amongst the most frequently visited of websites, not least because they provide regular updates on current events. As competition between news websites increases, they are making noticeable efforts to increase their readership. It is important to remain aware, however, that a website's success depends on more than just the number of visits. Its stability and competitiveness depend on having a loyal readership that returns to the pages of the website regularly. Journalists must deal with the complicated relationship between clicks and users' interest on a daily basis. Although there is still an effort to produce quality content, it is not easy to stay out of current trends in online marketing. We can see that the editorial offices are driven to follow daily quantitative targets, especially on news websites. Researchers and news professionals have tended to assume a close correspondence between clicks and audience interests (Kormelink and Meijer, 2017: 2). Other research shows that journalists select as the most newsworthy articles substantially more public-affair stories than their readership does (Boczkowski and Mitchelstein, 2013: 45). Research has shown that four fifths of Europeans used the internet in 2016 (Eurostat, 2017). The Digital Single Market (2016a) also offers the percentage of all consumers who use the internet for reading online newspapers and magazines. According to research the European Union (EU) reached on average $70.2 \%$ (Digital Single Market, 2016a) and in comparison with all consumers, we can see differences in the case of student users. Other research has looked at the readership for online newspapers in the $16-24$ age group. The mentioned group reached in EU 68.1 \% (Digital Single Market, 2016b). Survey data shows the percentage of the Slovak population reached via different media - print newspaper reading (29\%), radio listening (65\%) and television watching (83 \%) (Median SK, 2016). The reach of (general) internet usage is now $80.5 \%$ of individuals in Slovakia (Digital Single Market, 2016c). We can see that all university students (research population) use the internet every day. The quantitative numbers show that print, radio and TV content has been replaced by online content (Reuters Institute, 2016: 14).

\section{THEORETICAL OVERVIEW}

Although several studies have contributed to the understanding of online audiences (Aranyi and van Schaik, 2015; Boczkowski and Mitchelstein, 2013; Cockburn and McKenzie, 2000), there is relatively little information on users' loyalty to specific news media. It is, however, possible to identify several studies that touch on this area in the current literature. The most relevant are those that discuss the loyalty of online readers to news 
sites (Flavián et al., 2006b) or to websites in general (Toufaily et al., 2013; Ribbink et al., 2004; Flavián and Gurrea, 2008). This study concerns the student users' loyalty to news websites in Slovakia and sets out the factors that motivate users to return to selected news websites. We classify them as usability, familiarity, satisfaction and reputation. These are variables that we hypothesise have a direct and positive relationship with the loyalty of the users of Slovak news websites.

\section{Loyalty}

The study of loyalty in online behaviour has developed gradually in line with interest in Internet shopping, but its fundamental characteristics remain the same in respect of online media. In response to the increasing importance of Internet services, some researchers have begun to search for ways to increase customers' loyalty to a website and to attract potential customers on the Internet. One finding is that loyalty on the web depends on a consumer's experience of navigating and controlling a given site (Flavián et al., 2006b). Marketing professionals and academics have both emphasised that one of the main objectives of marketing is to create a clientele who come back - in other words, to build customer loyalty. Loyalty on the Internet has been described by several authors, who have tried to arrive at a definition. It has been called the probability that the same user will make a return visit to a given website (Srinivasan et al., 2002; Toufaily et al., 2013). It is a long-term effect that is influenced by many direct and indirect factors. For news websites, it is important to know who their readers are and how loyal they are to the website.

\section{Usability}

As the number of daily visitors to news websites increases, their operators are seeking ways to make their services more broadly accessible. We hypothesise that this is directly linked to the navigability, clear organisation and functionality of the website concerned. Consumer behaviour and loyalty are also positively affected by the design of a website, its graphical elements and the ease of use of its functions (Cockburn and McKenzie, 2000). The usability of a website is one of the conditions for building customer loyalty, including acquiring loyal users of a news website. The concept of usability refers to the benefits that consumers experience when it is easy to navigate through the content of a website. The definition of website usability may also include an attribute of quality in terms of the ease with which users can access the standard features of the website. This includes the question of how easy it is to understand the structure of the system, its functions, the web interface and the content available to users. The presentation of text and its organisation into paragraphs play a role in this (Horváth, 2016: 141).

\section{Familiarity}

Familiarity is a well-established element of Internet research and is a key factor affecting users' decisions on whether or not to read a site's content (Flavián and Gurrea, 2006; Flavián et al., 2006b). This means that there are grounds to believe that familiarity is the factor that gradually changes a user's sporadic, vague interactions with a website into deliberate, regular use. It gradually becomes easier for the user to decide which website to visit (Flavián and Gurrea, 2008: 32) and reduces the time necessary for initial 
orientation. Familiarity can be understood as the impression that people have of a given product or service based on their prior contact with it (Flavián et al., 2006b: 364). It is also the means by which a user's initial uncertainty about a product is overcome (Casaló et al., 2015: 1831), which in the present paper means the initial uncertainty about using a news website. Familiarity makes the user feel that the given news website is important for them. It also reduces indecisiveness and simplifies relations for both sides - the news website and the user.

\section{Satisfaction}

Several authors have observed that consumers' loyalty to a website is influenced by their satisfaction with the site (Toufaily et al., 2013: 1441; Ribbink et al., 2004: 446; Horppu et al., 2008: 403). This can be defined in general terms as the emotional state that results from an overall assessment of all the important factors contributing to the consumer's relationship with the site (Casaló et al., 2008: 327). Satisfaction can also be linked to a consumer or user's subjective attitude to a news website (Toufaily et al., 2013: 1441). It can be understood in general from two points of view. The first view is of satisfaction as a permanent emotional predisposition based on economic factors such as quantities sold or profits earned. The other viewpoint relates to non-economic satisfaction, which includes psychological factors such as the fulfilment of mutual promises or the troublefree functioning of the relevant relationships (Casaló et al., 2008: 327). This indicates that satisfaction is closely related to trust (Ribbink et al., 2004: 448) even in online marketing. In online news, this relationship begins from the launch of a news website and the way in which it initially distinguishes itself from its competitors.

\section{Reputation}

The concept of reputation has been addressed in numerous studies (Horppu et al., 2008: 404; Flavián and Guerrea, 2008: 30) of websites (Flavián and Guerrea, 2008; Casaló et al., 2008) and users' relationship to them (Flavián et al., 2006b). Web site reputation reflects the company's correct, fair and honourable behaviour to its customers (Flavián and Guerrea, 2008: 29). In the case of news websites, it comes from the effort not to disappoint users' trust in any way. As competition between online media increases, this is the only way to create a loyal group that can be defined, with reference to the concept of reputation, as a group that uses the offered services and also promotes the good name of a given news website. Reputation and the effort to build it can also be a motivating factor that increases the loyalty of a news website's users. Links to content on social media promote that content and help the brand stand out from competitors amongst competing websites.

\section{AIM OF THE STUDY}

The study focuses on users' loyalty to news websites and the aim of the study is to test the correlation of usability, familiarity, satisfaction and reputation with the users' loyalty to news websites by using correlation analysis. This paper develops a scale for 
measuring variables of loyalty, usability, familiarity, satisfaction and reputation (Table 2). The other variables are tested with respect to loyalty. We assume that there are positive relationships between the mentioned variables. Another primary aim of the study presented in this article is to identify the variables which influence users' loyalty to news websites. Building on the theoretical background given for the listed variables, we raise four research questions (RQ):

RQ1: Is there any relationship between a news website's usability and the loyalty of its student users?

RQ2: Is there any relationship between a news website's familiarity and the loyalty of its student users?

RQ3: Is there any relationship between a news website's satisfaction and the loyalty of its student users?

RQ4: Is there any relationship between a news website's reputation and the loyalty of its student users?

This research is focused on young people studying for bachelor's and master's degrees at universities in Slovakia. Students were chosen because they prefer digital news (Reuters Institute, 2016: 27). As a follow-up, students were asked to choose one news website which they visit most frequently for digital news. It is assumed that consumers of news actively select news sources, and that certain sources or devices are preferred over others to follow world events (Picone, 2016: 130). A final assumption is that university students represent a research population in which it is possible to test the variables defined below.

\section{Formulation and reasoning of hypotheses}

Our hypotheses $(\mathrm{H} 1, \mathrm{H} 2, \mathrm{H} 3, \mathrm{H} 4)$, as we listed below, are based not only on the aforementioned research but also on a three-year observation of the habits of university students' use of news websites to obtain information. 'The process of formulating the hypotheses also included a series of qualitative interviews. In our view, the aforementioned theoretical material and the findings of our qualitative research suggested that users' loyalty to a news website was based on multiple factors.

The layout of components and the design used by a website would appear to play an important role in motivating users to return to a website. This is also related to the site's overall adaptation to users' standards and habits (Flavián et al., 2006a; Flavián et al., 2006b: 367; Casaló et al., 2008: 329). The first variable we consider is usability. The assumptions and theoretical basis for formulating a hypothesis about this variable are supported by the results of research into its association with loyalty in the online space (Flavián et al., 2006b: 371; Casaló et al., 2008: 339). It has also been noticed that users of news websites state that their perception of the usability of a website has an effect on their satisfaction and trust in relation to the website and their choice of which news website to use (Flavián and Guerrea, 2008: 36). This factor was also correlated with the use

\footnotetext{
1 The survey was carried out from 2013 to $2015(\mathrm{~N}=122)$. It was designed to test a specific hypothesis and therefore care must be taken not to over-generalise from its conclusions. We were interested in the daily habits of university students related to the use of news websites.
} 
of particular web applications (Matera et al., 2006: 2). Our research therefore suggests that there is a direct relationship between usability and users' loyalty to news websites and we therefore propose the following hypothesis:

$\mathrm{H} 1$ : There is a direct positive relationship between a news website's usability and the level of loyalty.

Empirical analyses indicate that usability and familiarity influence user's choice of which news website to read for information on current affairs (Flavián and Guerrea, 2008: 38). It is expected that when a user selects a news website, they will repeatedly return to the site and become part of its loyal group. Our research also covers the relationship between familiarity and loyalty, with the concept of familiarity being of key importance in the relationship between a user's loyalty and their experience of a website. In our view, familiarity is positively correlated with a user's individual loyalty to a news website. A user who reports greater familiarity will also be more loyal to a news website (Flavián et al., 2006b: 366). Furthermore, it has been found that there is a stronger relationship between familiarity and loyalty the more experience users have of using a website's services (Flavián et al., 2006b: 371). There are thus grounds to believe that loyalty to a website also depends on its familiarity and therefore the following hypothesis is proposed:

$\mathrm{H} 2$ : There is a direct positive relationship between a news website's familiarity and the level of loyalty.

In our view satisfaction will also be correlated with the other studied variables, especially loyalty. When we examine the relationship between satisfaction and loyalty, we expect to find a relationship between the two variables (Picón et al., 2014: 747) because a high level of satisfaction leads to a greater level of individual loyalty (Casaló et al., 2008: 329; Flavián et al., 2006a: 8), also in combination with the user's level of trust in the website (Flavián et al., 2006a: 8; Flavián and Guinalíu, 2006: 602). This expectation is based primarily on the results of studies of the relationship between satisfaction and loyalty on the Internet (Horppu et al., 2008: 403). Our aim is to investigate satisfaction in the context of news websites and to highlight the role that users play in this, building upon the work of Carlos Flavián and Raquel Gurrea (2008: 39). We assume that young people's loyalty to a news website is particularly dependent on their overall satisfaction with their first use of it. Satisfaction can result from, amongst other things, the pleasure of using an easily navigated website (Matera et al., 2006: 5-6). In order to determine whether the variables of satisfaction and loyalty are related to each other, the following hypothesis is proposed:

H3: There is a direct positive relationship between a news website's satisfaction and the level of loyalty.

There is also thought to be a relationship between the reputation of a news website and the loyalty of its users. Reputation is expected to have a direct, positive effect on the size of a site's readership (Flavián and Gurrea, 2008: 32). It may influence the spread of awareness of a product via the Internet and can help increase the loyalty of users of a given 
website (Casaló et al., 2008: 329). There are grounds to expect that a strong reputation will motivate users to recommend a website to other readers of online newspapers (Casaló et al., 2015: 1831). It is likely that in the given sample of university students, reputation and the related recommendation of news to others will be manifested mainly on social networks. The reputation of a website is most relevant when a new website is launched for a newspaper that was previously published in print. To test whether the described relationship between reputation and loyalty exists, the following hypothesis is proposed:

$\mathrm{H} 4$ : There is a direct positive relationship between a news website's reputation and the level of loyalty.

\section{METHODOLOGY}

The given hypotheses were tested by using correlation analysis. The correlation analysis helps us to reveal relationships between researched variables and predict how variables affect other variables. We used the Pearson Correlation to measure the strengths of association between the variables. The variables of usability, familiarity, satisfaction, reputation were tested against the variable of loyalty. The statistical term for correlation - Pearson Correlation coefficient is ( $r$ ). Correlations $(r)$ range from -1.00 to + 1.00 - no relationship between the variables ( 0.00 correlation); weak correlation (.00 to $.25)$; moderate correlation (.26 to .50); strong correlation (.51 and above) (Croucher, CronnMills, 2015, 276). We also carried out a Student $t$-test ${ }^{2}$ to test the differences between the group of male and female participants. There were no significant differences between them and we carried out the rest of the correlation analysis with a single group. Gender bias has not influenced the result.

\section{Measuring scales}

In developing scales on which to measure the studied variables, we drew inspiration from multi-item scales which have been used several times in multiple research studies (Table 1). The studies from which the individual measurement scales were taken were also of assistance in the definition of the studied variables as they relate to the users of news websites.

Table1. Scale for measuring variables

\begin{tabular}{ll} 
Variable/Scale & Adapted from \\
\hline Usability & $\begin{array}{l}\text { Casaló et al., 2008; Flavián and Gurrea, 2006; Flavián et al., 2006a; } \\
\text { Flavián et al., 2006b; Roy et al., 2001 }\end{array}$ \\
\hline Familiarity & Casaló et al., 2008; Flavián and Gurrea, 2006; Flavián et al., 2006b \\
\hline
\end{tabular}

\footnotetext{
$\overline{2}$ loyalty: t-test: $\mathrm{t}(408)=1,11 ; \mathrm{p}>0,05(\mathrm{p}=, 0,262) ;$ usability: $\mathrm{t}$-test: $\mathrm{t}(408)=0,233 ; \mathrm{p}>0,05(\mathrm{p}=, 0,815)$; familiarity: $\mathrm{t}$-test: $\mathrm{t}$ $(408)=0,381 ; p>0,05(p=, 0,381)$; satisfaction: $t$-test: $\mathrm{t}(408)=1,12 ; \mathrm{p}>0,05(\mathrm{p}=, 0,262)$; reputation: $\mathrm{t}$-test: $\mathrm{t}(408)=1,31$; $\mathrm{p}>0,05(\mathrm{p}=, 0,196)$.
} 


\begin{tabular}{ll} 
Variable/Scale & Adapted from \\
\hline Satisfaction & Casaló et al., 2008; Flavián et al., 2006a; Picón et al., 2014; Ribbink et al., 2004 \\
Reputation & Casaló et al., 2008; Flavián and Gurrea, 2006; Ganesan, 1994 \\
Loyalty & $\begin{array}{l}\text { Casaló et al., 2008; Flavián et al., 2006a; Flavián et al., 2006b; } \\
\text { Flavián and Guinalíu, 2006; Picón et al., 2014; Ribbink et al., 2004; } \\
\text { Yoon and Kim, 2000 }\end{array}$ \\
\hline
\end{tabular}

It was important to study the work of authors who had already carried out research in similar areas using the same multi-item scales. Our research concerned the variables of loyalty, usability, familiarity, satisfaction and reputation. The works from which the questions concerning the variables were taken are listed in Table 1 and the questions themselves are listed in Table 2. The content of the questions was adapted from a general online orientation to focus specifically on news websites. The questions in Table 2 were adapted from research papers where the mentioned variables were tested. Each scale for measuring variables is based on a number of questions -3 for loyalty, 5 for usability, 3 for familiarity, 4 for satisfaction and 4 for reputation. These numbers come from previous testing as Table 1 shows. The research questions listed in Table 2 were modified and updated during the past years. The respondents answered them in the questionnaire with reference to the news website which they selected. The questions had to be translated into Slovak and the translations were tested for comprehensibility with a small group of respondents $(\mathrm{N}=15)$. We did not find any incomprehensible phrasings resulting from the translation of individual items. The questionnaire was created in digital form on Google's systems and was completed online. It was distributed to respondents through email addresses at particular universities, faculties and departments and was shared on social networks. The questionnaire was sent to 14 universities in Slovakia. Respondents came from 52 departments (social sciences, natural sciences, humanities and arts). The universities and the departments were selected by a random selection from a list on the website. Data was collected in the period from May 2015 to March 2016. The respondents were asked to respond to 26 questions in a questionnaire. The variables were measured using a 7-point Likert scale (Flavián et al., 2006b) on a one-dimensional model. The respondents were asked to choose one news website which they visit most frequently for information on domestic and foreign events. They then answered the subsequent questions in the questionnaire with reference to this site. Following the recommendations of authors who had conducted similar research, respondents were given a free choice of one of the sites for testing (Casaló et al., 2008: 332; Flavián et al., 2006b). The test questions included socio-demographic characteristics and questions on the variables under consideration, in the form of 19 items scored on a 7-point Likert scale ${ }^{3}$ giving a potential range of 19 to 133 points.

\footnotetext{
$\overline{3}$ All questions were measured on a seven-point Likert scale. The respondents can score from 1 - strongly agree to 7 -strongly disagree (from questionnaire: Strongly agree - 1. 2. 3. 4. 5. 6. 7. - Strongly disagree).
} 
IZVORNI ZNANSTVENI RAD / DOI: 10.20901/ms.8.15.5 / PRIMLJENO: 06.09.2016.

Table 2. Scales of loyalty, usability, familiarity, satisfaction and reputation

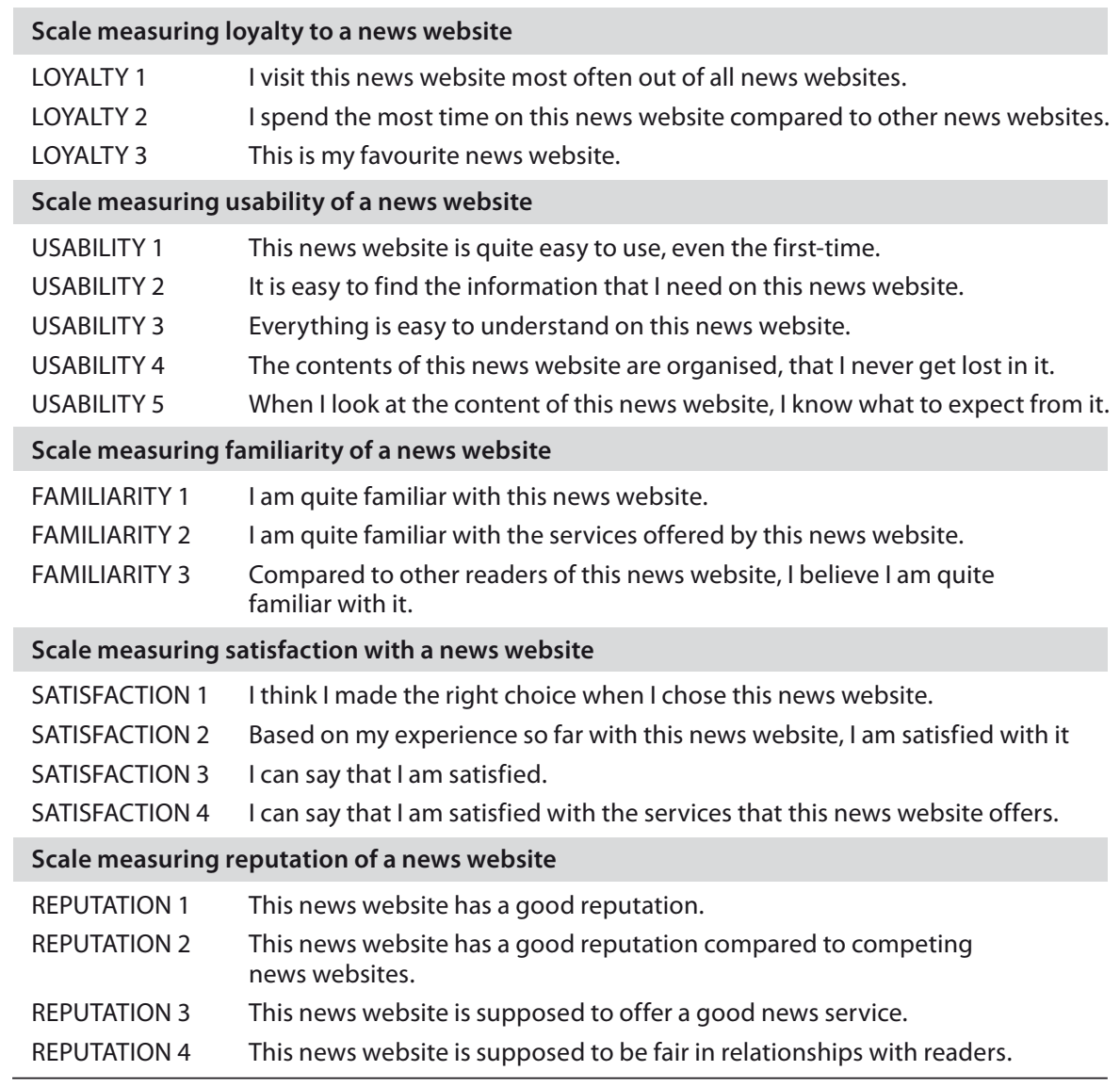

\section{Sampling}

The research population was young people studying for bachelor's and master's degree at universities in Slovakia. The research sample included students $(\mathrm{N}=408)$ at universities in every region of Slovakia. The average age of the respondents was 21.5 years (SD 2.19) with a median of 21.0 years. The participants in the research were $35.05 \%$ male and $64.95 \%$ female. The mean time that university students spent reading content on their selected news websites was 59.4 (SD 92.4) minutes, with a median of 30.0 minutes. As regards the main means used to access new websites, the studies sample of university students most frequently connected using a notebook (72.27 \%), followed by a mobile telephone (19.88\%), a PC (6.13\%) and in last place, using a tablet (1.72\%). 


\section{Analysis of reliability}

The individual test questions had already been standardised in a number of previous studies which are referred to above. The results of Cronbach's alpha test show an adequate and acceptable level of internal consistency. In all cases the value was above 0.7 , which can be considered sufficient (Flavián and Gurrea, 2008). The value of Cronbach's a was 0.755 in the case of usability, 0.843 in the case of familiarity, 0.902 in the case of loyalty, 0.899 in the case of satisfaction and 0.921 in the case of reputation.

\section{Testing of hypotheses}

The given hypotheses were tested by calculating the Pearson correlation coefficient (Figure 1). For each hypothesis, there were two interval variables.

\begin{tabular}{l|l} 
USABILITY & $0.392^{* *}\left(\mathrm{R}^{2}=0.15\right)$ \\
FAMILIARITY & $0.484^{* *}\left(\mathrm{R}^{2}=0.23\right)$ \\
\hline SATISFACTION & $0.625^{* *}\left(\mathrm{R}^{2}=0.39\right)$ \\
\hline REPUTATION & $0.528^{* *}\left(\mathrm{R}^{2}=0.28\right)$ \\
\hline
\end{tabular}

In the case of all the tested hypotheses $(\mathrm{H} 1, \mathrm{H} 2, \mathrm{H} 3, \mathrm{H} 4)$, the null hypothesis was rejected with less than $5 \%$ risk and their alternatives were adopted.

LOYALTY

$\Delta$ Figure 1.

Correlation Coefficients ( $r$ )

** Correlation is significant at the 0.01 level (2-tailed)

H1: The value of the Pearson correlation coefficient is 0.392 and the significance achieved is $p=, 001, r=0.392 p<0.01(p=0.001)$ There is a statistically significant relationship between the level of usability of a news website and the level of loyalty.

$\mathrm{H} 2$ : The value of the Pearson correlation coefficient is 0.484 and the significance achieved is $p=, 001, r=0.484 p<0.01(p=0.001)$ There is a statistically significant relationship between the level of familiarity of a news website and the level of loyalty.

H3: The value of the Pearson correlation coefficient is 0.625 and the significance achieved is $p=, 001, r=0.625 p<0.01(p=0.001)$ There is a statistically significant relationship between the level of satisfaction with a news website and the level of loyalty.

H4: The value of the Pearson correlation coefficient is 0.528 and the significance achieved is $p=, 001, r=0.528 p<0.01(p=0.001)$ There is a statistically significant relationship between the level of reputation of a news website and the level of loyalty. 


\section{RESULTS}

The results of the testing of our hypotheses show that the studied variables, which we hypothesised would be related to users' loyalty to news websites, show a direct and positive relationship with it. The conclusion is that all the studied hypotheses can be accepted. Our test has identified a strong relationship between loyalty and the studied variables of usability, familiarity, satisfaction and reputation. The strongest relationship was found between news website users' satisfaction and loyalty (H3) and between reputation and loyalty (H4). From this it can be concluded that if users meet the criteria for satisfaction with a selected news website that they use, they will also be loyal to it. At the same time, the strength of the relationship that reputation has been found to have with loyalty suggests that a good name plays an important role in the selection of one news website over its competitors. The test of the relationship between familiarity and loyalty $(\mathrm{H} 2)$ also indicated a strong relationship. The same applies in the case of usability and loyalty $(\mathrm{H} 1)$, although in this case the achieved correlation coefficient indicates a more moderate relationship. Although the hypotheses were accepted and there are strong indications of a direct and positive relationship between the studied variables (Figure 1), a regression analysis found a relatively low value of $R^{2}$, especially for the relationship between usability and loyalty $\left(R^{2}=0.15\right)$, but also for those between familiarity and loyalty $\left(R^{2}=0.23\right)$ and between reputation and loyalty $\left(R^{2}=0.28\right)$. This finding shows that there are other variables that affect users' loyalty to news websites.

\section{DISCUSSION AND CONCLUSIONS}

Our research shows that news websites are a major source of information for young people studying at university. The studied variables are important for their decisions on which news websites they return to. Although the assumptions, on which our work is based, including the definitions of the studied variables, were developed in the study of commercial websites, news websites do not operate in a fundamentally different way and the definitions are relevant. The variables that support the existence of a functional and successful website (Table 1) also play an important role in the part of the online space studied in this paper. Our findings highlight the variables that influence and shape the loyalty of users of news websites. They can also be a stimulus for the operators of news websites to intensify their efforts to produce high-quality content or an attractive design which, along with other variables - as our regression analysis shows - influence users' loyalty. Focussing on loyal users is a good strategy in the face of current challenges such as market consolidation, the relatively large amount of competition and site owners' ambitions to charge for content.

The correlations between the studied variables show that the strongest direct and positive relationship is that between satisfaction and loyalty. We have seen that a user's satisfaction with a particular news website and its services is a key factor for developing loyalty to the site, in the same way as other authors (Casaló el al., 2008: 338; Flavián et al., 2006a: 8; Ribbink et al., 2004: 452) have shown satisfaction to affect users' loyalty to 
websites in general. It should be noted that users participating in the research gave a positive score to satisfaction with the choice of a studied site and its services. Their evaluation depended on prior experience of the site. It would be beneficial for future research to investigate the variables that influence users' satisfaction with the websites that they visit and to determine what events that would cause them to transfer to a competitor.

The results of the testing of the hypotheses in our research for the present paper show that reputation has a direct and positive relationship with loyalty. The reputation of a website is thus one of the most important aspects supporting the loyalty of its users. This variable was also found to have a positive and significant relationship in research where the user of a website is viewed as a consumer and reputation is defined as an intangible matter that is the basis of effective management (Casaló el al., 2008: 338-339). Certain authors who have studied the effect of reputation on the selection of digital daily newspapers say that there is no significant relationship where we can suppose that the selection of this content is based on reputation (Flavián and Gurrea, 2008: 38). Our study did not focus on digital daily newspapers in general but on news websites. The research for this variable also included questions concerning a news website's good name in comparison with competitors in the same area. The findings indicate that the selection of one news website over its competitors does depend on its good name and its declared independence from its owner, which has also been shown to be a not insignificant factor for the retention of loyal users.

The research has also found a statistically significant relationship between users' familiarity with a news website and their loyalty to it. Because the hypothesis regarding these variables was adopted, familiarity can be designated another of the main factors that contribute to the development of a loyal readership for a news website. Site operators should therefore not underestimate the fact that users are more likely to return to their website if they identify with its content or services. The relevance of familiarity for decisions about where to read news online has been indicated in previous research into the reading of newspapers' online editions (Flavián and Gurrea, 2008: 38). It should be noted that it is only meaningful to consider the correlation of familiarity with the loyalty of users of news websites when the users already have experience of reading news on the internet (Flavián et al., 2006b: 371), but this requirement is met in our study, considering the age of the respondents and the time that they spend reading online.

In the results of the research, the relationship between usability and loyalty is statistically significant, even if it is the weakest relationship out of the studied correlations. From this we conclude that the design and typography of news websites, the layouts of their control elements and the overall ease with which they can be used have an important role in building a loyal user base. The authors of related research have also emphasised that usability is a particularly significant factor for the loyalty of users with greater experience of using the Internet (Flavián et al., 2006b: 371). We have found that most news websites are relatively easy to navigate, with straightforward placement of controls and other measures designed to increase usability (Flavián and Gurrea, 2008: 39). The same 
applies in the case of news applications on smartphones, which $20 \%$ of respondents said that they used for browsing news. In the world of print and broadcast media, the news is largely conceived as a good that is consumed primarily before and after work and outside the workplace (Boczkowski, 2010: 2), but smartphones are changing the way that digital news is consumed. We can suppose the discrepancy between our results and those mentioned above is caused by situation that university students spend so much time using their notebooks, as our result shows (72.2\%). Students may be considered a relatively atypical group and the presented scale needs to be tested on other segments of the population.

There are certain restrictions and limits on the interpretation of the findings of our research. All the respondents were students at universities in Slovakia. Future research into user loyalty would benefit from studying a broader population. This is necessary if more general conclusions are to be drawn from the research. It would also be useful to compare the habits of users in other countries because the websites in the present study were all in Slovak. We suggest the scale could be tested with experienced and novice users as participants and could evaluate different content subsections of the selected site (Aranyi and van Schaik, 2015).

Another area that our findings have shown to need more attention is the interrelationships between the studied variables and other factors that could also help news websites to acquire a loyal readership for their content. A useful next step could be to study users' interactions with such content and the connection to loyalty.

The developed scale for measuring usability, familiarity, satisfaction, reputation and loyalty could be used in future to study existing news sites regarding the political orientation of the editorial board or the users of a selected news site. Digital news is becoming a part of public sphere in which political interests play a crucial role. Therefore, it would also be useful to test a sizeable thematic range in the online news choices of journalists and consumers (Boczkowski and Mitchelstein, 2013: 45). The future work may involve testing different digital platform, such as mobile phones, PCs and tablets.

\section{References}

>Aranyi, Gabor and van Schaik, Paul (2015) Testing a Model of User-Experience with News Websites. Journal of the Association for Information Science and Technology 67 (7): 1-21. DOI: 10.1002/asi.23462. >Boczkowski, Pablo J. (2010) News at Work: Imitation in an Age of Information Abundance. Chicago: The University of Chicago Press. DOI: 10.7208/chicago/9780226062785.001.0001.

>Boczkowski, Pablo J. and Mitchelstein, Eugenia (2013) The News Gap: When the Information Preferences of the Media and the Public Diverge. Cambridge: MIT Press. DOI: 10.7551/ mitpress/9780262019835.001.0001.

>Casaló, Luis; Flavián, Carlos and Guinalíu, Miguel (2008) The Role of Perceived Usability, Reputation, Satisfaction and Consumer Familiarity on the Website Loyalty Formation Process. Computers in Human Behavior 24 (2): 325-345. DOI: 10.1016/j.chb.2007.01.017. >Casaló, Luis; Flavián, Carlos; Guinalíu, Miguel and Ekincic, Yuksel (2015) Avoiding the Dark Side of Positive Online Consumer Reviews: Enhancing Reviews' Usefulness for High Risk-Averse Travellers. Journal of Business Research 68 (9): 1829-1835. DOI: 10.1016/j.jbusres.2015.01.010. 
$>$ Cockburn, Andy and McKenzie, Bruce (2000) What Do Web Users Do? An Empirical Analysis of Web Use. International Journal of Human-Computer Studies 54 (6): 903-922. DOI: 10.1006/ijhc.2001.0459. >Digital Single Market (2016a) Reading Online Newspapers/Magazines. https://goo.gl/a8Wdao (14.05.2017). >Digital Single Market (2016b) Reading Online Newspapers/Magazines. https://goo.gl/Zr98QK (14.05.2017). >Digital Single Market (2016c) Reading Online Newspapers/Magazines. https://goo.gl/U0l8tf (14.05.2017).

$>$ Eurostat (2017) Internet Access and Use Statistics - Households and Individuals. http://ec.europa. eu/eurostat/statistics-explained/index.php/Internet_access_and_use_statistics_-_households_ and_individuals (16.05.2017).

>Flavián, Carlos and Guinalíu, Miguel (2006) Consumer Trust, Perceived Security and Privacy Policy: Three Basic Elements of Loyalty to a Web Site. Industrial Management \& Data Systems 106 (5): 601620. DOI: 10.1108/02635570610666403.

>Flavián, Carlos and Gurrea, Raquel (2008) Reading Newspapers on the Internet: the Influence of Web Sites' Attributes. Internet Research 18 (1): 26-45. DOI: 10.1108/10662240810849577.

>Flavián, Carlos and Gurrea, Raquel (2006) The Choice of Digital Newspapers: Influence of Reader Goals and User Experience. Internet Research 16 (3): 231-247. DOI: 10.1108/10662240610673673. >Flavián, Carlos; Guinalíu, Miguel and Gurrea, Raquel (2006a) The Role Played by Perceived Usability, Satisfaction and Consumer Trust on Website Loyalty. Information \& Management 43 (1): 1-14. DOI: 10.1016/j.im.2005.01.002.

>Flavián, Carlos; Guinalíu, Miguel and Gurrea, Raquel (2006b) The Influence of Familiarity and Usability on Loyalty to Online Journalistic Services: The Role of User Experience. Journal of Retailing and Consumer Services 13 (5): 363-375. DOI: 10.1016/j.jretconser.2005.11.003.

$>$ Ganesan, Shankar (1994) Determinants of Long-Term Orientation in Buyer-Seller Relationship. Journal of Marketing 58 (2): 1-19. DOI: 10.2307/1252265.

>Horppu, Marianne; Kuivalainen, Olli; Tarkiainen, Anssi and Ellonen, Hanna-Kaisa (2008) Online Satisfaction, Trust and Loyalty, and the Impact of the Offline Parent Brand. Journal of Product \& Brand Management 17 (6): 403-413. DOI: 10.1108/10610420810904149.

>Horváth, Miloš (2016) Štylistika súčasného slovenského jazyka (Stylistics of Contemporary Slovak Language). Bratislava: Univerzita Komenského.

>Kormelink, Groot and Meijer, Costera (2017) What Clicks Actually Mean: Exploring Digital News user practices. Journalism (January 2017): 1-16. DOI: 10.1177/1464884916688290.

>Matera, Maristella; Rizzo, Francesca and Toffetti Carughi, Giovanni (2006) Web Usability: Principles and Evaluation Methods, pp. 143-180 in Mendes Emilia and Mosley Nile (eds) Web Engineering. Berlin, Heidelberg: Springer. DOI: 10.1007/3-540-28218-1_5.

>Median SK (2016) Národný prieskum spotreby, médií a životného štýlu (Ongoing Multi-Client Research of Consumer Behaviour, Media Consumption and Lifestyle) http://www.median.sk/ pdf/2016/ZS164SR.pdf (14.05.2017).

>Picón, Araceli; Castro, Ignacio and Roldán, José (2014) The Relationship between Satisfaction and Loyalty: A Mediator Analysis. Journal of Business Research 67 (5): 746-751. DOI: 10.1016/j. jbusres.2013.11.038.

>Picone, Ike (2016) Grasping the Digital News User: Conceptual and Methodological Advances in News Use Studies. Digital Journalism 4 (1): 125-141. DOI: 10.1080/21670811.2015.1096616. $>$ Reuters Institute (2016) Reuters Institute Digital News Report. Reuters Institute for the Study of Journalism. http://reutersinstitute.politics.ox.ac.uk/sites/default/files/Digital-News-Report-2016. pdf?utm_source=digitalnewsreport.org\&utm_medium=referral (16.05.2017).

$>$ Ribbink, Dina; Allard, van Riel; Liljander, Veronica and Streukens, Sandra (2004) Comfort your Online Customer: Quality, Trust and Loyalty on the Internet. Managing Service Quality 14 (6): 446456. DOI: 10.1108/09604520410569784. 
IZVORNI ZNANSTVENI RAD / DOI: 10.20901/ms.8.15.5 / PRIMLJENO: 06.09.2016.

$>$ Roy, Marie; Dewit, Oliver and Aubert, Benoit (2001) The Impact of Interface Usability on Trust in Web Retailers. Internet Research: Electronic Networking Applications and Policy 11 (5): 388-398. DOI: 10.1108/10662240110410165.

$>$ Srinivasan, Srini; Andersona, Rolph and Ponnavolub, Kishore (2002) Customer Loyalty in E-Commerce: an Exploration of its Antecedents and Consequences. Journal of Retailing 78 (1): 41-50. DOI: 10.1016/S0022-4359(01)00065-3.

$>$ Toufaily, Elissar; Ricard, Line and Perrien, Jean (2013) Customer Loyalty to a Commercial Website: Descriptive Meta-Analysis of the Empirical Literature and Proposal of an Integrative Model. Journal of Business Research 66 (9): 1436-1447. DOI: 10.1016/j.jbusres.2012.05.011.

>Yoon, Sung-Joon and Kim, Joo-Ho (2000) An Empirical Validation of a Loyalty Model Based on Expectation Disconfirmation. Journal of Consumer Marketing 17 (2): 120-126. DOI: $10.1108 / 07363760010317196$. 


\section{STUDENTI KAO LOJALNI KORISNICI INFORMATIVNIH MREŽNIH STRANICA: KAKO FAKTORI UPOTREBLJIVOSTI, POZNATOSTI, ZADOVOLJSTVA I REPUTACIJE KORELIRAJU S LOJALNOSTI KORISNIKA}

\section{Ján Hacek}

SAŽETAK Izdavačima informativnih mrežnih stranica važno je u vrijeme rastuće konkurencije $u$ online vijestima zadržati lojalne korisnike. Ovaj rad doprinosi proučavanju lojalnosti istraživanjem faktora koji djeluju na lojalnost mladih korisnika informativnih mrežnih stranica i motiviraju ih na ponovno posjećivanje. Uzorak u ovom istraživanju čine studenti $(N=408)$ sa sveučilišta u Slovačkoj koji svaki dan koriste informativne mrežne stranice u potrazi za informacijama. Korelacijska i regresijska analiza korištene su za testiranje hipoteza. Rezultati istraživanja potvrđuju da su faktori upotrebljivosti, poznatosti, zadovoljstva i reputacije u izravnoj i pozitivnoj vezi s lojalnosti korisnika, što se odražava u svakodnevnom korištenju informativnih mrežnih stranica. Lojalnost je osobito blisko povezana s reputacijom i zadovoljstvom s odabranim informativnim mrežnim stranicama. Regresijska analiza također pokazuje da postoje i druge varijable koje djeluju na lojalnost korisnika.

\section{KLJUČNE RIJEČI}

LOJALNOST, KORELACIJA, INFORMATIVNE MREŽNE STRANICE, STUDENTI KORISNICI, LOJALNI KORISNICI

Bilješka o autoru

Ján Hacek :: Sveučilište Comenius, Filozofski fakultet, Odsjek za novinarstvo, Bratislava, Slovačka :: jan.hacek@uniba.sk 